\title{
ADRENOCORTICAL RESPONSE TO GENERAL ANAESTHESIA AND SURGERY
}

\author{
H. Ishimara, K. Ishida, A. Matsuki, T. Kudo, and T. OYama
}

THE NUMBER of glucocorticoid-treated patients has been increasing.' Although adrenocortical insufficiency during anaesthesia and surgery in these patients has rarely been documented, adrenocortical reserve in these circumstances appears to be important. ${ }^{3}$ The present study was undertaken to evaluate adrenocortical response to exogeneous ACTH during anaesthesia and surgery as judged by plasma concentrations of cortisol in patients with normal and subnormal adrenocortical function.

\section{METHODS}

Fifty-five patients ranging in age from 19 to 58 years were studied, as shown in Table I. Fifty subjects had no history of steroid therapy and were free from hepatic, renal or endocrine disease. They were divided into the following five groups of 10 patients each:

(1) Fentanyl group: These patients were anaesthetized with nitrous oxide-oxygen-droperidol and fentanyl. In this group droperidol and fentanyl were administered separately and the initial doses of these two drugs were less than those in group 2 (Innovar) being droperidol $0.15 \mathrm{mg} / \mathrm{kg}$ and fentanyl $0.2 \mathrm{mg}$ (Table I).

(2) Innovar group: These patients received Innovar with nitrous oxide and oxygen. This group differs from the fentanyl group in the use of the fixed proportion mixture of droperidol and fentanyl and the initial dose in this group represents droperidol $0.25 \mathrm{mg} / \mathrm{kg}$ and fentanyl $0.005 \mathrm{mg} / \mathrm{kg}$ (Table $\mathrm{l}$ ).

(3) Pentazocine group: who had nitrous oxideoxygen droperidol-pentazocine anaesthesia.

(4) Thiopentone group; who received nitrous oxide-oxygen-thiopentone anaesthesia.

(5) Halothane group: who received halothane nitrous oxide-oxygen anaesthesia.

A sixth group consisted of five glucocortocoid-treated patients, whose adrenocortical hypofunction had been established by a rapid

H. Ishihara, M.D., K. Ishida, M.D., A. Matsuki, M.D. T. Kudo, M.D. Fellows, and T. Oyama, M.D., Professor of Anaesthesiology, Hirosaki University Medical School, Hirosaki, Aomori-ken, Japan.
ACTH test one week before the operation. These were anaesthetized with nitrous oxideoxygen droperidol-fentanyl. The mean dosage of glucocorticoid which had been administered ranged from 4.9 to $8.6 \mathrm{~g}$ expressed as the equivalent dose of cortisol. None of them received steroid on the day before or on the day of the operation until the patient had recovered adequately from anaesthesia in the recovery room.

The normal range of our ACTH test is as follows.' (1) Plasma concentrations of cortisol above $12.0 \mu \mathrm{g} / 100 \mathrm{ml}$ at 8:30 a.m. (2) Plasma concentration of cortisol above $17.0 \mu \mathrm{g} / 100 \mathrm{ml} 30 \mathrm{mi}$ nutes after intramuscular injection of synthetic ACTH (beta 1-24 corticotrophin) $0.25 \mathrm{mg}$. (3) The increase in plasma concentration of cortisol is more than $5.0 \mu \mathrm{g} / 100 \mathrm{ml}$. If at least two of the three conditions are below normal ranges, the patient is considered to have subnormal adrenocortical function.

Each patient was premedicated with oral pentobarbitone $100 \mathrm{mg}$ the night before and again 90 minutes before induction of anaesthesia. Meperidine $35 \mathrm{mg}$ and atropine $0.5 \mathrm{mg}$ were given intramuscularly 60 minutes before induction of anaesthesia. In consideration of the diurnal variations in concentration of plasma cortisol, the induction of anaesthesia started at $8: 30 \mathrm{a.m}$. in all patients.

Synthetic ACTH $0.25 \mathrm{mg}$ was given by intramuscular injection just before induction by one of the anaesthetic sequences. As shown in Table $I$, induction was followed by intravenous succinylcholine chloride $\mathbf{4 0} \mathrm{mg}$ for tracheal intubation, and maintenance was by the appropriate anaesthetic sequence, again as shown in Table $I$. Anaesthesia alone continued for at least $45 \mathrm{mi}$ nutes before the start of the operation. Ventilation was controlled manually or assisted throughout the procedure. D-tubocurarine 3-6 $\mathrm{mg}$ was injected to obtain adequate muscle relaxation when required during the operation.

Eight blood samples were withdrawn from each patient at the following times: 8:30 a.m., immediately before the induction of anaesthesia; three times during anaesthesia alone; four times after the start of the operation and in the recovery 
TABLE I

PATIEnTS STUded

\begin{tabular}{|c|c|c|c|c|c|}
\hline \multirow[b]{2}{*}{ Group } & \multirow{2}{*}{$\begin{array}{l}\text { No. of } \\
\text { patients }\end{array}$} & \multirow{2}{*}{$\begin{array}{l}\text { Age } \\
(\mathrm{yr})\end{array}$} & \multirow{2}{*}{$\underset{(\mathrm{kg})}{\text { B.W. }}$} & \multicolumn{2}{|c|}{ Anaesthetic Method } \\
\hline & & & & Induction & Maintenance \\
\hline Hypoadrenal & 5 & $37 \pm 6$ & $52 \pm 5$ & $\begin{array}{l}\text { droperidol }(0.15 \mathrm{mg} / \mathrm{kg}) \\
+ \text { fentanyl }(0.2 \mathrm{mg})^{*}+\mathrm{N}_{2} \mathrm{O}\end{array}$ & Fentanyl $\dagger+\mathrm{N}_{2} \mathrm{O}$ \\
\hline Fentanyl & 10 & $34 \pm 5$ & $53 \pm 2$ & $\begin{array}{l}\text { droperidol }(0.15 \mathrm{mg} / \mathrm{kg}) \\
+ \text { fentanyl }(0.2 \mathrm{mg})^{*}+\mathrm{N}_{2} \mathrm{O}\end{array}$ & Fentanyl $\dagger+\mathrm{N}_{2} \mathrm{O}$ \\
\hline Thalamonal & 10 & $36 \pm 4$ & $54 \pm 2$ & $\begin{array}{l}\text { Thalamonal }(0.10 \mathrm{ml} / \mathrm{kg}) \\
+\mathrm{N}_{2} \mathrm{O}\end{array}$ & Fentanyl $\dagger+\mathrm{N}_{2} \mathrm{O}$ \\
\hline Pentazocine & 10 & $37 \pm 4$ & $57 \pm 3$ & $\begin{array}{l}\text { droperidol }(0.15 \mathrm{mg} / \mathrm{kg}) \\
\text { + pentazocine }(45 \mathrm{mg})\end{array}$ & Pentazocinet $\mathrm{N}_{2} \mathrm{O}$ \\
\hline Thiopentone & 10 & $36 \pm 5$ & $55 \pm 2$ & thiopentone $(4-6 \mathrm{mg} / \mathrm{kg})$ & Thiopentonet $+\mathrm{N}_{2} \mathrm{O}$ \\
\hline Halothane & 10 & $45 \pm 5$ & $56 \pm 3$ & halothane $(0.5-1.5 \%)$ & Halothane $+\mathrm{N}_{2} \mathrm{O}$ \\
\hline
\end{tabular}

room when the patient had recovered adequately fiom anaesthesia. Plasma concentrations of cortisol were determined according to the method of Rudd, et al. ${ }^{2}$ Student's t-test-was used for the statistical analysis.

\section{Results}

1. Adrenocortical response in patients not sreated with glucocorticoid

The mean corisol levels before induction of anaesthesia in the fentanyl, Innovar, ${ }^{*}$ pentazocine, thiopentone and halothane groups were $15.6 \pm 2.0 \mu \mathrm{g} / 100 \mathrm{ml}$ (S.E.), $13.9 \pm$ $1.3 \mu \mathrm{g} / 100 \mathrm{ml}, 12.7 \pm 1.2 \mu \mathrm{g} / 100 \mathrm{ml}, 13.6 \pm$ $2.0 \mu \mathrm{g} / 100 \mathrm{ml}$ and $14.4 \pm 1.4 \mu \mathrm{g} / 100 \mathrm{ml}$ respectively as shown in Figure 1. No statistically significant differences were found in the preinduction cortisol levels among these five groups. In the fentanyl group the cortisol levels increased significantly to $28.5 \pm 1.8 \mu \mathrm{g} / 100 \mathrm{ml}(\mathrm{P}<0.01) 30$ minutes after the start of anaesthesia. A further increase to $33.0 \pm 2.2 \mu \mathrm{g} / 100 \mathrm{ml}$ was observed 30 minutes after the start of the operation. The plasma concentrations of cortisol remained elevated until the patient had recovered adequately from anaesthesia in the recovery room. A similar pattern in plasma levels of cortisol was found in the other four groups.

2. Adrenocortical responses in hypo-adrenal patients

The plasma cortisol levels in the five hypoadrenal patients ranged from 1.5 to 7.5 (mean 3.8) $\mu \mathrm{g} / 100 \mathrm{ml}$ at 8:30 a.m. One week before the oper-

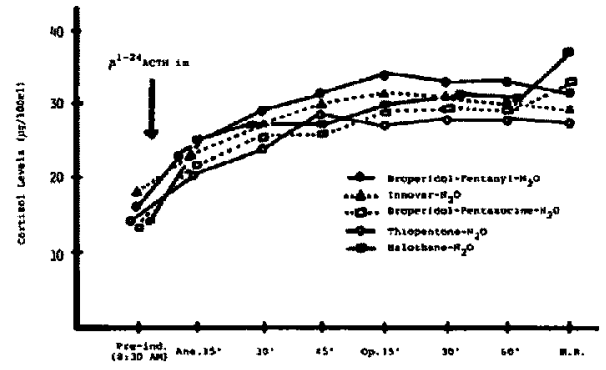

Figure I Plasma cortisol levels during anaesthesia and surgery in patients without hypoadrenal function.

ation, as shown in Table II. At 30 minutes following administration of intramuscular ACTH, plasma cortisol levels ranged from 1.0 to 12.5 (mean 7.3) $\mu \mathrm{g} / 100 \mathrm{ml}$. On the operative day the pre-anaesthetic control levels varied from 0.5 to 10.5 (mean 4.1 ) $\mu \mathrm{g} / 100 \mathrm{ml}$. No appreciable increase was noted during anaesthesia or operation as compared with pre-induction level. The surgical stress failed to increase the plasma concentration of cortisol as shown in Figure 2.

3. Mean arterial pressure in patients not treated with glucocorticoid and in hypo-adrenal patients.

Mean arterial pressure at $\mathbf{3 0}$ minutes after the induction of anaesthesia decreased slightly in each group, but the change was not statistically significant. This decrease was followed by a slight increase at $\mathbf{3 0}$ minutes after the start of the operation. Severe hypotension was not encountered in any group. 
TABLE II

Plasma Cortisol Levels after Intramuscular $\boldsymbol{B}^{1-24}$ ACTH in Patients WITH AdRenocortical Hypofunction

\begin{tabular}{ccccc}
\hline & $\begin{array}{c}\text { One week before operation } \\
(\mu \mathrm{g} / 100 \mathrm{ml})\end{array}$ & $\begin{array}{c}\text { During droperidol }+ \text { fentanyl }+\mathrm{N}_{2} \mathrm{O} \text { anaesthesia } \\
(\mu \mathrm{g} / 100 \mathrm{ml})\end{array}$ \\
\hline Case & Control & $30 \mathrm{~min}$. after* & Control & $30 \mathrm{~min}$. after* \\
\hline B.S. & 2.5 & 1.0 & 0.5 & 2.5 \\
S.A. & 4.0 & 12.5 & 4.0 & 10.0 \\
T.O. & 3.5 & 12.0 & 4.0 & 9.5 \\
N.M. & 7.5 & 9.0 & 10.5 & 9.5 \\
M.K. & 1.5 & 2.0 & 1.5 & 2.5 \\
Mean \pm S.E. & $3.8 \pm 1.3$ & $7.3 \pm 3.1$ & $4.1 \pm 2.3$ & $6.8 \pm 2.2$ \\
\hline
\end{tabular}

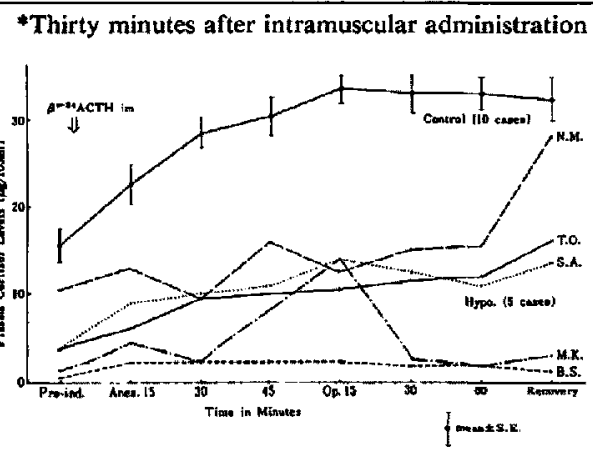

FIgure 2 Plasma cortisol levels during anaesthesia and surgery in hypoadrenal patients.

\section{Discussion}

Our data indicate that, in anaesthetized patients who have not been treated with glucorticoids, ACTH administration evokes an increase of about 80 per cent in the plasma concentration of cortisol over control levels 30 minutes after intramuscular injection. In contrast the plasma concentration of cortisol increased 36 per cent after the same injection of ACTH in unanaesthetized subjects

This would imply that adrenocortical response to exogeneaus ACTH is more pronounced in anaesthetized than in unanaesthetized subjects. Although plasma levels of cortisol during anaesthesia and surgery depend mainly upon adrenal secretion, other factors such as hepatic metabolism and urinary excretion of cortisol are also involved. Therefore, a more detailed study would be needed to clarify this phenomenon.

It is well known that the plasma concentration of cortisol is influenced by anaesthetics. ${ }^{3}$ During anaesthesia and surgery the adrenocortical response to exogeneous ACTH in the present study showed no remarkable difference between vari- ous anaesthesia groups as judged by plasma levels of cortisol. Reier, et af. ${ }^{4}$ observed that the intravenous administration of 25 units of ACTH 60 minutes after the induction of morphine anaesthesia ( $4 \mathrm{mg} / \mathrm{kg}$ ) evoked about a 400 per cent increase in the plasma concentration of cortisol over the pre-induction levels 30 minutes after the ACTH injection. Even in elderly patients the adrenocortical response to anaesthesia and major surgery was reported to be adequately preserved, although plasma concentration of cortisol was measured without administration of ACTH. ${ }^{5}$ The plasma levels of 11-hydroxycorticoid 30 minutes after 25 units of intramuscular ACTH during operations under halothane and methoxyflurane anaesthesia has been measured earlier by Nishioka, et al. They found $^{2} 73$ per cent increase in the halothane group and 155 per cent increase in the methoxyflurane group over preinduction levels, 30 minutes after ACTH administration. However, the mean pre-induction plasma levels of 11-hydroxycorticoid were higher in the halothane $\mathbf{2 6 . 8}$ $\mu \mathrm{g} / 100 \mathrm{ml}$ ) than in the methoxyflurane group $(20.8 \mu \mathrm{g} / 100 \mathrm{ml})$. This might have contributed to the difference.

The present study shows that the adrenocortical response to anaesthesia and surgery is reduced in glucocorticoid-treated patients even after stimulation by ACTH. However there was no close relationship between plasma levels of cortisol and mean arterial pressure. It is known that cortisol is not a prime factor in the maintenance of arterial pressure during anaesthesia and surgery in glucocorticoid-treated patients. ? Keblet, ef al.$^{8.9}$ found no significant differences between glucocorticoid supplemented and nonsupplemented patients both as far as plasma levels of catecholamine and post-operative plasma volume are concerned. Gordon, et al. ${ }^{10}$ 
have suggested that routine glucocorticoid "cover" would be unneccessary for operations in glucocorticoid-treated patients. AbdelSalam and Davis" reported a case of acute adrenal crisis during appendectomy under general anaesthesia in an occult Addisonian, whose preoperative examination had revealed no remarkable abnormalities except for hyponatraemia. Circulatory collapse was reversed immediately with external heart compression, oxygen inhalation and administration of sodium bicarbonate without the use of glucocorticoid.

Recent studies have demonstrated that adrenocortical insufficiency was likely to develop in the postoperative period, especially in patients with gram negative sepsis or debilitating prolonged illness. ${ }^{12.13}$ Although prolonged steroid therapy might lead to postoperative adrenal haemorrhage, ${ }^{14}$ it is difficult to predict accurately the possibility of precipitating adrenal crisis during and after anaesthesia and surgery in glucocorticoid-treated patients.

It has been demonstrated that during anaesthesia and surgery, when optimal homeostasis of body fluid and electrolytes are maintained, severe hypotension or circulatory collapse are rarely encountered even if supplement of steroid is omitted. However, supplementary preoperative, intra-operative and postoperative steroid therapy should be emphasized, ${ }^{15,16}$ because we have to eliminate the unrecognized risk of adrenal failure. Furthermore, Meyers 17 reported depressed neuromuscular transmission in patients with adrenocortical insufficiency.

The present study demonstrates that the preoperative ACTH test was reliable in evaluating adrenocortical response to anaesthesia and surgery. It is therefore recommended that preoperative assessment of adrenocortical function should be done in glucocorticoid-treated patients and in patients in whom adrenocortical hypofunction is suspected.

\section{SUMMARY}

The effects of stimulation by synthetic ACTH (beta 1-24 corticotrophin) on the adrenocortical response, judged from plasma levels of cortisol, were studied during general anaesthesia and surgery in 55 adult patients. Fifty patients had not been treated with glucocorticoid, another five patients had hypoadrenocortical function due to the glucocorticoid treatment. ACTH $0.25 \mathrm{mg}$ was administered intramuscularly immediately before the induction of anaesthesia. Plasma levels of cortisol 30 minutes after the induction with various different anaesthetics were increased about 80 per cent in patients who had not been treated with glucocorticoids. The plasma concentrations of cortisol remained elevated until the patient had recovered from anaesthesia in the recovery room.

No appreciable increase in the plasma cortisol was observed in the glucocorticoid-treated patients. These patients had been considered to have reduced adrenal function as judged by the results of the rapid ACTH test, carried out one week before operation. These results suggest that in patients who have not been treated with glucocorticoids the adrenocortical response to exogeneous ACTH during general anaesthesia and surgery is well preserved, and is increased when compared to surgical subjects who have not been stimulated with ACTH. However, in the glucocorticoid-treated patients, adrenocortical response was reduced as judged from the plasma cortisol concentration after stimulation by ACTH administration during general anaesthesia and surgery. Therefore, the preoperative evaluation of adrenocortical function should be emphasized in glucocorticoid-treated patients and in patients in whom adrenocortical hypofunction is suspected.

\section{RÉSUMÉ}

Les effets de la stimulation de l'ACTH synthétique (bèta 1-24 corticotrophine) sur la réponse corticosurrénalienne, mesurés par le dosage plasmatique du cortisol, ont été étudiés chez 55 patients adultes pendant l'anesthésie générale et la chirurgie. Cinquante de ces malades n'avaient jamais reçu de traitement aux glucocorticoïdes, alors que cinq présentaient un hypofonctionnement de la corticosurrénale causé par un traitement préalable aux glucocorticoïdes. Une dose d'ACTH $0.25 \mathrm{mg}$ a été administrée par la voie intramusculaire immédiatement avant l'induction anesthésique. Après 30 minutes d'anesthésie par différents agents, le niveau plasmatique de cortisol a augmenté de 80 pour cent chez ceux qui $n$ 'avaient pas suivi de traitement aux glucocorticoïdes et cette augmentation s'est maintenue jusqu'à la récupération du malade à la salle de réveil.

Cette élévation ne s'est pas retrouvée chez les patients traités par les glucocorticoídes. Chez eux, on a jugé que la fonction de la corticosurrénale était diminuée comme l'indiquait le test de réponse rapide à l'ACTH fait une semaine avant l'opération. Ces résultats portent à croire, 
d'une part, que chez les malades qui n'ont pas déjà été traités aux glucocorticoïdes, la réponse à l'ACTH exogène est bien conservée pendant l'anesthésie générale et la chirurgie, et est augmentée lorsqu'on la compare à celle des opérés non stimulés par l'ACTH. D'autre part, chez les malades préalablement tíaités aux glucocorticoïdes, la réponse de la corticosurrénale est diminuée comme en fait foi la concentration plasmatique de cortisol après la stimulation par l'ACTH. En conclusion, l'évaluation préopératoire de la fonction corticosurrénalienne s'avère importante chez les malades préalablement traités aux glucocorticoides et chez ceux qui sont suspects d'insuffisance corticosurrénalienne.

\section{REFERENCES}

1. Oyama, T.\& Takiguchi, M. Prediction of adrenal hypofunction in anaesthesia. Canad. Anaesth. Soc. J. 19: 239 (1972).

2. RUDD, B.T. COWER, J.M. \& Crawford, N. The determination of plasma free hydrocortisone and corticosterone by a combined fluorimetric and modified Porter-Silber procedure. Clin. Chem. Acta 6: 686 (1961)

3. Orama, T. Anaesthetic management of endocrine disease, Springer-Verlag, Berlin, Heidelberg, New York, 39 (1973).

4. Reier, C.E., George, J.M., \& Kilman, J.W. Cortisol and growth hormone response to surgical stress during morphine anesthesia. Anesth. Analg. 52: 1003 (1973).

5. Bowen, D.J. \& RIChardson, D.J. Adrenocortical response to major surgery and anesthesia in elderly patients. Brit. J. Anaesth, 46: 873 (1974).

6. NishiokA, K., LeVY, A.A., \& DOBKIN, A.B. Ef- fect of halothane and methoxyfurane anaesthesia on cortisol concentration in relation to major surgery. Canad. Anaesth. Soc. J. 15: 441 (1968).

7. Kehlet, H. \& Binder, C. Adrenocortical function and clinical course during and after surgery in unsupplemented glucocorticoid-trealed patient. Brit. J. Anaesth. 45: 1043 (1973).

8. Kehlet, H., Nikki, P., JaAttela, A., \& Takki, $S$. Plasma catecholamines during surgery in unsupplemented glucocorticoid treated patients. Brit. J. Anaesth. 40:73 (1974).

9. Kehlet, H., Engquist, A., \& Greibe, J. Plasma volume during surgery in unsupplemented glucocorticoid-treated patients. Brit. J. Aniesth. 46: 452 (1974).

10. Gordon, N.H., Scott, D.B., \& Percy Robe, I.W. Modification of plasma corticoid concentrations during and after surgery by epidural blockade. Brit. Med. J. 1: 581 (1973).

11. Abdelsal.am, A. \& Davies, D.M. Acute adrenal insufficiency during surgery. Brit. J. Anaesth. 46: 619 (1974).

12. Holdowicz, M. \& Szymanska, M. A case of acute adrenocortical failure on the second day following mitral commissurotomy. Anesth. Resuscit. Intens. Ther. 2: 373 (1974) (Abstract).

13. Hubay, C.A., Weckesser, E., \& Levy, R.P. Occult adrenal insufficiency in surgical patients. Ann. Surg. 181: 325 (1975).

14. Clark, O.H. Postoperative adrenal hemorrhage. Ann. Surg. 182: 121 (1975).

15. KeHter. H. A rational approach to dosage and preparation of parenteral glucocorticoid substitution therapy during surgical procedures. Acta Anaesth. Scand. 19: 260 (1975).

I6. Gran, L. \& Rahle, J.A. Rational substitution therapy for steroid-treated patients. Anaesthesia 33: 59 (1978).

17. MEYERS, E.F. Partial recovery from paneuronium neuromuscular blockade following hydrocortisone administration. Anesthesiology 46: 148 (1977). 